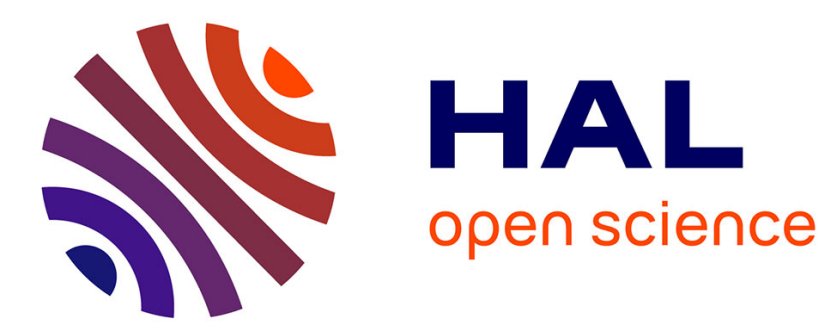

\title{
Probabilistic fatigue initiation assessment diagram pipe steel X52 influence of hydrogen
}

S Jallouf, Julien Capelle, Guy Pluvinage

\section{To cite this version:}

S Jallouf, Julien Capelle, Guy Pluvinage. Probabilistic fatigue initiation assessment diagram pipe steel X52 influence of hydrogen. Probabilistic fatigue initiation assessment diagram pipe steel x52: influence of hydrogen, May 2016, Dubrovnik, Croatia. hal-02972668

\section{HAL Id: hal-02972668 \\ https://hal.science/hal-02972668}

Submitted on 20 Oct 2020

HAL is a multi-disciplinary open access archive for the deposit and dissemination of scientific research documents, whether they are published or not. The documents may come from teaching and research institutions in France or abroad, or from public or private research centers.
L'archive ouverte pluridisciplinaire HAL, est destinée au dépôt et à la diffusion de documents scientifiques de niveau recherche, publiés ou non, émanant des établissements d'enseignement et de recherche français ou étrangers, des laboratoires publics ou privés. 


\title{
PROBABILISTIC FATIGUE INITIATION ASSESSMENT DIAGRAM
}

\section{PIPE STEEL X52 : INFLUENCE OF HYDROGEN}

\author{
S. Jallouf, ${ }^{1}$ J. Capelle ${ }^{2}$ and G. Pluvinage ${ }^{3}$ \\ ${ }^{1}$ State Materials Institute Darmstadt, Germany \\ ${ }^{2}$ LABPS Enim France 57078 \\ ${ }^{3}$ FM.C Silly-sur-Nied (France) 57530 \\ corresponding author : pluvinage @ cegetel.net
}

\begin{abstract}
A probabilistic fatigue Assessment Diagram (fAD) is proposed as a tool to guarantee a prescribed number of applied fatigue cycles with a conventional low probability of failure. The fatigue failure assessment curve is given by a power law described by two parameters: the fatigue initiation resistance and the fatigue initiation exponent. From the targeted applied stress range, it is possible to find the probability of failure and its associated safety factor. An example of fatigue life duration of a pipe steel submitted to hydrogen embrittlement is given.
\end{abstract}

Keywords: probabilistic fatigue failure assessment diagram, pipe steel

\section{Nomenclature}

b Basquin's exponent

$f_{s}$ safety factor

$\mathrm{f}_{\mathrm{r}}$ fatigue parameter

$f_{S, \sigma}$ partial safety factor for stress

$f_{S, N}$ partial safety factor for the number of cycles

$\mathrm{CV}$

Coefficient of variation

$I_{\text {cath }}(\tau)$ cathodic polarisation current

$\mathrm{P}_{\mathrm{r}}$ loading parameter

$\mathrm{N}_{\mathrm{r}}$ the number of applied cycles to failure

$\mathrm{N}_{\mathrm{u}}$ maximum number of cycles for the LCF domain

$\mathrm{N}^{*}$ number of applied cycles associated to a design probability of failure

$P$ failure probability

P* probability of failure associated with assessment point

$Q_{H}^{e v}$ total quantity of hydrogen

$\mathrm{N}_{\mathrm{D}}$ the number of cycles for the endurance limit

$\mathrm{X}$ parameter

$\beta$ fatigue exponent

$\Delta \sigma$ stress range

$\mu$ mean

$\sigma$ standard deviation

$\sigma^{\prime}{ }_{i}$ fatigue initiation resistance

$$
\begin{aligned}
& \sigma_{y} \text { Yield stress } \\
& \sigma_{f}^{\prime} \text { coefficient of Basquin's law } \\
& \sigma_{u l \text { Ultimate strength }}
\end{aligned}
$$




\section{INTRODUCTION}

For defects that promote structural and component failure, the failure assessment diagram (FAD) is generally used as indicated by several codes [1]. However, input information for failure analysis like load or stress, fracture resistance or defect size, is stochastic; consequently, the FAD approach is deterministic. To take into account the uncertainties of the failure parameters and their statistical distributions, a fracture mechanics approach associated with Monte Carlo method [2] is used, called probabilistic fracture mechanics. Therefore, defect assessment is made by comparing the probability of failure with a safety reference. Loading and failure conditions are represented in a FAD by an assessment point with coordinates, the non-dimensional load and the non-dimensional crack driving force. The location of the assessment point below or behind the failure assessment indicates whether a risk of failure exists. Quantitatively, the position of the assessment point determines the safety factor in a deterministic FAD, or the probability of failure in a probabilistic FAD [2]. The failure assessment curve is different according to the codes, obtained as the lower bound of several fracture tests. It is an empirical curve; however, some theoretical failure curves have been proposed, but only in academic works on FAD. An extension of FAD was recently proposed for fatigue [3], called the fatigue assessment diagram (fAD). In the $\mathrm{fAD}$, the assessment point has coordinates: the non-dimensional load and the applied number of cycles.

Basquin's fatigue law is the basis of fAD; when limited to the high cycles fatigue regime, this is:

$$
\begin{gathered}
\Delta \sigma=\sigma_{u} \quad \text { if } N \leq N_{u} \\
\Delta \sigma=\sigma_{f}^{\prime} N_{r}^{-b} \text { if } N_{u}<N<N_{D} \\
\Delta \sigma=\sigma_{D} \quad \text { if } N \geq N_{D}
\end{gathered}
$$

where $\sigma_{f}^{\prime}$ is the coefficient of Basquin's law, and b Basquin's exponent. $\mathrm{N}_{\mathrm{r}}$ is the number of applied cycles at failure, $N_{u}$ the number of cycles for the LCF domain $\left(N_{u}=10^{4}\right.$ cycles) for $\Delta \sigma=\sigma_{u}$ the low cycle fatigue limit, and $N_{D}$ the number of cycles for the endurance domain $\left(N_{D}=10^{7}\right.$ cycles) for $\Delta \sigma=\sigma_{D}$ the endurance limit.

When extending to a probabilistic fAD, the fatigue failure curve is obtained from the mean value, i.e. for a fatigue failure probability of $\mathrm{P}=0.5$. This definition allows one to define the safety factor. This corresponds to the ratio between the mean stress range $\Delta \sigma\left(\mathrm{P}_{\mathrm{r}}=0.5, \mathrm{~N}=\mathrm{N}_{\mathrm{r}}\right)$ and the applied stress range corresponding to the probability of failure $\mathrm{P}^{*}$ for the same number of cycles $\mathrm{N}$ :

$$
f_{s}=\frac{\Delta \sigma\left(P=0.5 ; N=N_{r}\right)}{\Delta \sigma\left(P=P^{*} ; N=N_{r}\right)}
$$




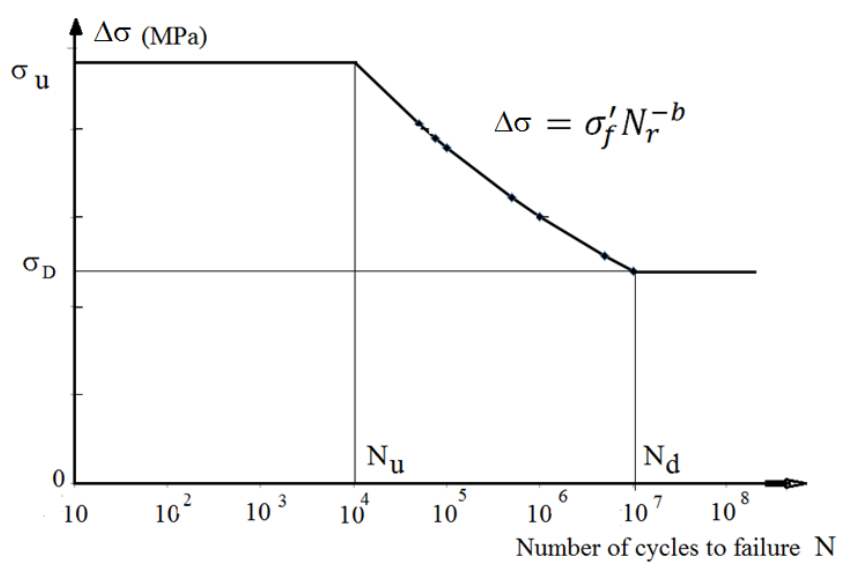

Fig. 1. Fatigue law used for the fatigue assessment diagram

Here, the sensitivity to hydrogen embrittlement of the pipe steel API L X52 is interrogated through the safety factor obtained from the fAD. An example is given to guarantee a fatigue life duration of 500000 cycles. The use of a safety factor of 10 on the number of cycles to failure is studied with the same tool.

\section{FATIGUE ASSESSMENT DIAGRAM}

In the fAD, Basquin's law defines the safe and unsafe domains in the number of cycles range $N_{u}<N<N_{d}$. The fatigue failure curve is characteristic of the material through Basquin's exponent and coefficient. The fatigue parameter $\mathrm{f}_{\mathrm{r}}$ is defined by the logarithm of the number of cycles to failure.

$$
f_{r}=\log _{10}\left(N_{r}\right)=f\left(P_{r}\right) \text { with } N_{u} \leq N_{r} \leq N_{d}
$$

The loading parameter $\mathrm{P}_{\mathrm{r}}$ is defined as:

$$
\left[\frac{\left(\Delta \sigma-\sigma_{D}\right)}{\left(\sigma_{u}-\Delta \sigma\right)}=P_{r}\right]
$$

Normalisation of the non-dimensional maximum applied stress is made by dividing by the range $\left(\sigma_{u}-\sigma_{D}\right)$. Therefore, the loading parameter $\mathrm{p}_{\mathrm{r}}$ varies in the range [0-100].

In the $\mathrm{fAD}$, an assessment point $\mathrm{O}$ is defined by its coordinates:

$$
\begin{aligned}
& P_{r}=P_{r}^{*} \\
& f_{r}=f_{r}^{*}
\end{aligned}
$$

Failure will occur by fatigue if the assessment point is below the fatigue failure assessment curve. The partial safety factor for the number of cycles $\mathrm{F}_{\mathrm{S}, \mathrm{N}}$ and the partial safety factor for stress $\mathrm{F}_{\mathrm{S}, \sigma}$. are defined according to the relative position of the assessment point from the fatigue failure assessment curve (Fig. 2).

$$
f_{S, N}=\frac{O A}{A B} ; f_{S, \sigma}=\frac{O C}{C D}
$$




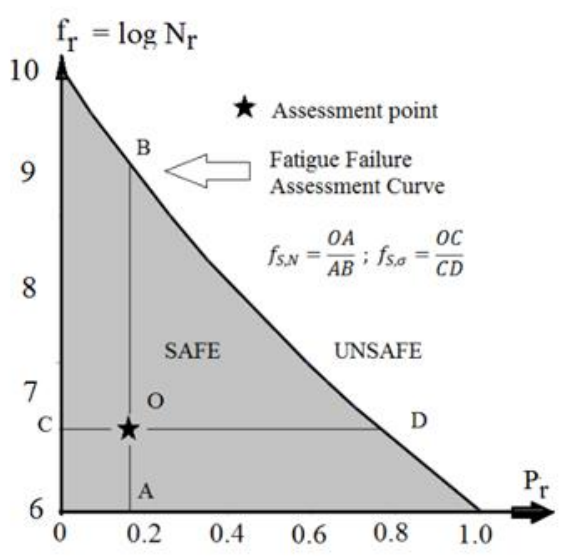

Fig. 2. Fatigue assessment diagram with the fatigue failure assessment curve and the assessment point $\mathrm{O}$; definition of partial safety factors for the number of cycles $\mathrm{F}_{\mathrm{s}, \mathrm{N}}$ and stress, $\mathrm{F}_{\mathrm{s}, \sigma}$.

\section{FATIGUE INITIATION CURVES FOR A PIPE STEEL X52: THE INFLUENCE OF HYDROGEN}

\subsection{Material}

The studied material is API 5L X52 grade pipeline steel. The yield stress and ultimate strength are reported in Table 1. Values of these mechanical properties after hydrogen absorption are also reported. We note a small increase in the yield stress (2.5\%) and an important reduction of elongation at failure (38\%).

Table 1: Tensile properties of API 5L X52 steel in air and with hydrogen absorption

\begin{tabular}{|c|c|c|c|}
\hline & $\begin{array}{c}\text { Yield stress } \\
\sigma_{y}(\mathrm{MPa})\end{array}$ & $\begin{array}{c}\text { Ultimate strength } \\
\sigma_{u l}(\mathrm{MPa})\end{array}$ & $\begin{array}{c}\text { Elongation } \\
\text { at failure A\% }\end{array}$ \\
\hline Air & 410 & 528 & 15.8 \\
\hline Hydrogen & 420 & 570 & 9.76 \\
\hline
\end{tabular}

\subsection{Test methods}

The fatigue resistance to initiation of the API 5L X52 steel was determined at room temperature using curved notched specimens, i.e. "Roman tile" specimens. The use of this type of specimen is justified by the fact that the pipe dimensions do not permit the use of a full thickness specimen [4].

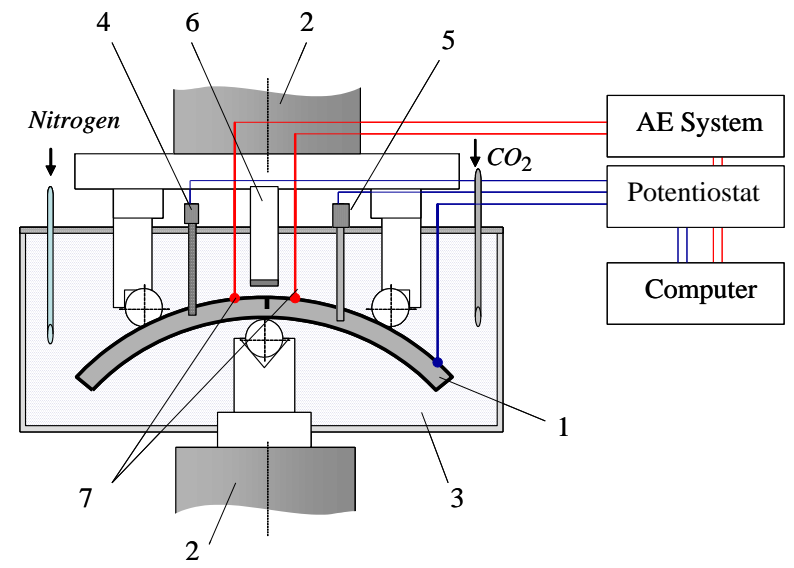

Figure 3: Roman Tile specimen fixture and assembly. Positions of electrodes for hydrogen charging. 1 - Roman tile specimen; 2 - Actuator; 3 -c orrosion cell with NS4 solution; 4 - pH electrode; 5 - Reference electrode; 6 Platinium auxilliary electrode; 7 - EA sensors. 
The "Roman tile" specimen is shown in Figure 3. The shape of the specimen is a circular arc with a central angle of $160^{\circ}, 60 \mathrm{~mm}$ long. The $\mathrm{V}$-notch has a notch opening angle of $45^{\circ}$ and a radius of $0.15 \mathrm{~mm}$; the notch depth a is equal to half the thickness..

The test setup of the three-point bend test is shown in Figure 3. The bend-test fixture is positioned on the closed loop hydraulic testing machine. Hydrogen charging was made using a corrosion cell filled with NS4 solution.

The test conditions are given in Table 2. Wöhler curves were drawn at both initiation and failure, but only the fatigue curves at initiation are presented here. The results are presented in a bi-logarithmic graph of stress amplitude versus the number of cycles to failure.

Table 2: Fatigue test conditions

\begin{tabular}{|l|l|}
\hline Shape of the cycle used & Sinusoidal \\
\hline Frequency & $0.05 \mathrm{~Hz}$ \\
\hline Load ratio & 0.5 \\
\hline Working potential & $-1 \mathrm{~V}_{\text {sce }}$ \\
\hline Electrolytic solution & Natural Soil 4 (NS4) \\
\hline Solution pH & $6.66-6.74$ \\
\hline
\end{tabular}

\subsection{Detection of fatigue initiation by acoustic emission}

The fatigue phenomenon consists of two parts: fatigue initiation and crack propagation until failure. The definition of the number of cycles to initiation depends on the resolution of the optical equipment. Here, fatigue initiation is detected by acoustic emission, which is more sensitive than the optical method.

Acoustic emission is recorded during the test by two sensors, as can be seen in position 7 in Figure 3 . An energy burst characterises fatigue initiation, helps in its detection with high reliability, and gives supplementary information on the location of the initiation.

\subsection{Hydrogen charging method}

Hydrogen charging of the specimen is made with a corrosion cell filled with NS4 solution. The chemical composition of this solution is given in Table 3.

Table 3: Chemical composition of NS4 solution (g/L)

\begin{tabular}{|c|c|c|c|}
\hline $\mathrm{NaHCO}_{3}$ & $\mathrm{KCl}$ & $\mathrm{CaCl}_{2}$ & $\mathrm{MgCl}_{2} \cdot \mathrm{H}_{2} \mathrm{O}$ \\
\hline 0.483 & 0.120 & 0.137 & 0.131 \\
\hline
\end{tabular}

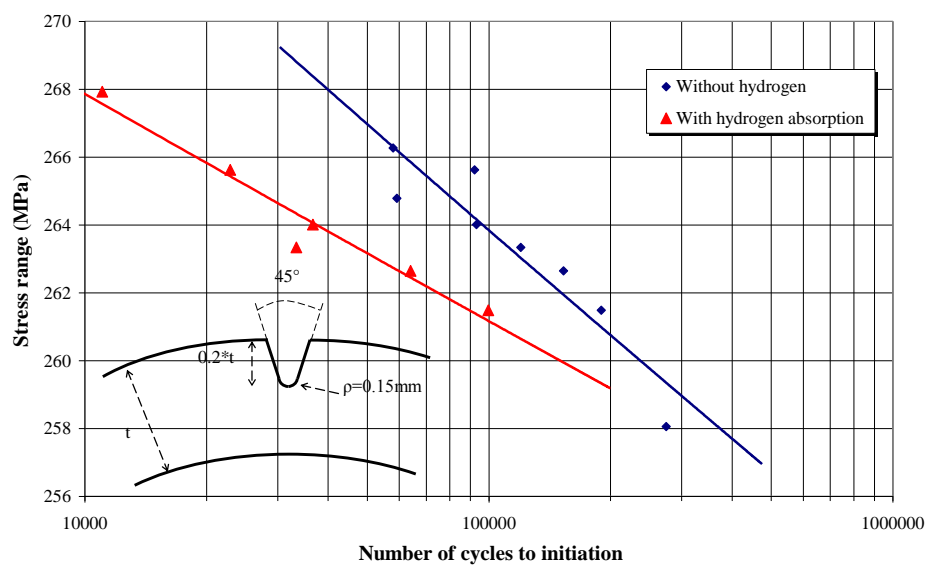

Fig. 4: Fatigue initiation resistance curves for Steel API 5L X52 with and without hydrogen absorption. 
A polarisation potential slightly more negative than the free corrosion potential for the studied steel is applied. By recording the cathodic polarisation current $I_{\text {cath }}(\tau)$, the hydrogen-charging process is controlled. The total quantity of evaluated hydrogen $Q_{H}^{e v}$ on the metal surface is:

$$
Q_{H}^{e v}=\int_{0}^{\tau_{\text {exp }}} I_{\text {cath }}(\tau) d \tau \quad \text { under } E_{\text {cath }}=\text { const. }
$$

\subsection{Experimental results}

Stress range versus the number of cycles to initiation is plotted in accordance with a power law:

$$
\Delta \sigma=\sigma_{i}^{\prime}\left(N_{i}\right)^{\beta}
$$

where $\sigma_{i}^{\prime}$ is fatigue initiation resistance and $\beta$ an exponent. $\Delta \sigma$ is the gross stress range. The results are presented in Table 4 and Fig. 4.

Table 4: Fatigue initiation resistance and $\beta$ exponent for steel API 5L X52

\begin{tabular}{|c|c|c|c|c|}
\cline { 2 - 5 } \multicolumn{1}{c|}{} & $\begin{array}{c}\text { Fatigue initiation } \\
\text { resistance } \sigma_{i}^{\prime}(\mathrm{MPa})\end{array}$ & Exponent $\beta$ & $\begin{array}{c}\sigma_{\mathrm{D}} \\
(\mathrm{MPa})\end{array}$ & $\begin{array}{c}\sigma_{\mathrm{u}} \\
(\mathrm{MPa})\end{array}$ \\
\hline Without & 336 & -0.0202 & 242 & 278 \\
\hline With hydrogen & 301 & -0.0121 & 247 & 269 \\
\hline
\end{tabular}

\section{PROBABILISTIC fAD}

In a probabilistic fAD, the probability of failure is plotted versus the loading parameter $\mathrm{p}_{\mathrm{r}}$, through iso-cycle fatigue lines. Fig.5 exhibits three zones: the fatigue endurance, the low cycle fatigue and the fatigue zone. The purpose of this kind of graph is to find a conventional probability of fatigue failure and a guarantee of the minimum number of in-service loading cycles, the associated loading parameter $p_{r}^{*}$. Fig. 5 gives an example for the pipe steel API 5L X52, the procedure to use a probabilistic fatigue assessment diagram (PfAD). An assessment point was obtained and is indicated by a black star for a targeted guarantee of non-fatigue failure during $10^{5}$ cycles with a probability of $16 \%(\mu-\sigma)$. The associated loading parameter is $P_{r}^{*}$. *

The safety factor $\mathrm{f}_{\mathrm{s}}$ is defined as the ratio between the loading parameter $\mathrm{p}_{\mathrm{r} . \mu}(\mathrm{P}=0.5)$ (associated with the mean value of the double-truncated distribution for the expected life duration), and the value $\mathrm{P}_{\mathrm{r}}\left(\mathrm{P}=\mathrm{P}^{*}\right)$, associated with the chosen conventional probability of failure:

$$
f_{s}=\frac{p_{r . \mu}(P=0.5)}{p_{r}^{*}\left(P=P^{*}\right)}
$$

In Fig. 5, the safety factor is simply given by:

$$
f_{s}=\frac{A C}{A B}
$$

The distribution of the stress range for a prescribed value of the number of cycles to failure was computed using the Monte Carlo method. The parameters of the fatigue law $\sigma_{i}^{\prime}$ and $\beta$, the endurance limit $\sigma_{\mathrm{D}}$ and the low cycle fatigue limit are assumed to be randomly distributed. An upper limit of the coefficient of variation $\mathrm{CV}=0.1 \mathrm{was}$ chosen for conservative reasons according to [5], as reported in Table 5. 


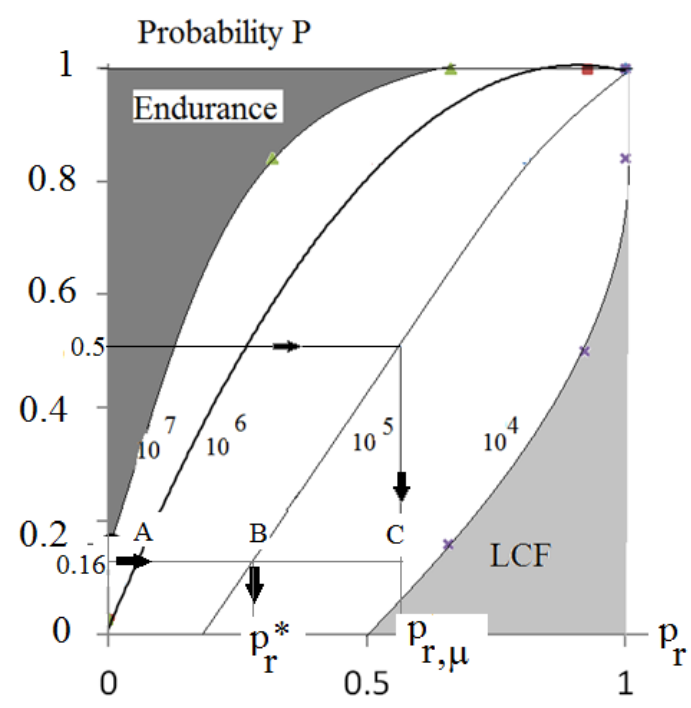

Fig. 5. Probabilistic fatigue assessment diagram (PfAD) for X52 pipe steel.

Table 5. Randomly distributed parameters and values of coefficients of variation

\begin{tabular}{|c|c|c|c|c|c|}
\hline Parameters & $\sigma_{i}^{\prime}$ & $\beta$ & $\mathrm{N}$ & $\sigma_{u}$ & $\sigma_{D}$ \\
\hline Distribution & Normal & Normal & Normal & Normal & Normal \\
\hline $\mathrm{CV}$ & 0.1 & 0.1 & 0.1 & 0.1 & 0.1 \\
\hline
\end{tabular}

The safety factor to be applied on the stress range, if we intend to guarantee a life duration of more than $\mathrm{N}_{\mathrm{r}}$ cycles with a probability $\mathrm{P}(\mathrm{X}<\mu-\sigma)$, is given in Table 6 . The mean and standard deviation are computed from the double-truncated stress range distribution $\sigma_{u} \geq \Delta \sigma \geq \sigma_{D}$.

Table 6. Safety factor associated with a probability

of $\mathrm{P}(\mathrm{X}<\mu-\sigma)$ to guarantee $\mathrm{Nr}$ loading cycles

$\begin{array}{cccc} & \Delta \sigma(\mathrm{MPa}) & \Delta \sigma(\mathrm{MPa}) & \\ \mathrm{N}_{\mathrm{r}} \text { (Air) } & \mathrm{P}(\mathrm{X}=0.5) & \mathrm{P}(\mathrm{X}<\mu-\sigma) & \mathrm{f}_{\mathrm{s}} \\ 10000 & 300.5 & 267.8 & 1.12 \\ 100000 & 292.32 & 259.8 & 1.12 \\ 1000000 & 284.2 & 251.9 & 1.12 \\ 10000000 & 276.4 & 244.39 & 1.13 \\ \mathrm{~N}_{\mathrm{r}} & & & \\ \text { (Hydrogen }) & \mathrm{P}(\mathrm{X}=0.5) & \mathrm{P}(\mathrm{X}<\mu-\sigma) & \mathrm{f}_{\mathrm{s}} \\ 10000 & 269.2 & 239.9 & 1.12 \\ 100000 & 261.8 & 232.7 & 1.12 \\ 1000000 & 254.6 & 225.7 & 1.12 \\ 10000000 & 247.6 & 218.91 & 1.13\end{array}$

In Table 6, the safety factor applied to the stress range is constant; however, the fatigue life duration and $\mathrm{f}_{\mathrm{s}}$ is not sensitive to hydrogen embrittlement. For the same life duration, under hydrogen embrittlement and for the pipe steel API 5L X52, the stress range decreases by $11 \%$; for any life duration. The distribution of the number of cycles to failure has been computed also using the Monte Carlo method for two prescribed stress ranges: $\Delta \sigma=$ $260 \mathrm{MPa}$ and $\Delta \sigma=270 \mathrm{MPa}$. The number of cycles to failure follows a normal distribution with a high level of confidence, as indicated by the Anderson Darling test (AD) [6] values reported in Table 7. 
Table 7: Distribution parameters $(\mu, \sigma$ and $\mathrm{CV})$ of the number of cycles to failure in air and under a hydrogen environment for two levels of applied stress ranges.

\begin{tabular}{|l|c|r|r|r|}
\hline & \multicolumn{1}{|c|}{ air } & \multicolumn{1}{l|}{$\mathrm{H}_{2}$} & air & \multicolumn{1}{l|}{$\mathrm{H}_{2}$} \\
\hline$\Delta \sigma(\mathrm{MPa})$ & \multicolumn{1}{|c|}{260} & 260 & 270 & 270 \\
\hline Distribution & Normal & Normal & Normal & Normal \\
\hline $\mathrm{AD}$ & 0.892 & 0.818 & 0.829 & 0.816 \\
\hline Deterministic & $3.28 \mathrm{E}+05$ & $1.87 \mathrm{E}+05$ & $5.07 \mathrm{E}+04$ & $8.27 \mathrm{E}+03$ \\
\hline$\mu$ probabilistic & $3.25 \mathrm{E}+05$ & $1.87 \mathrm{E}+05$ & $5.04 \mathrm{E}+04$ & $8.28 \mathrm{E}+03$ \\
\hline$\sigma$ & $3.24 \mathrm{E}+04$ & $1.85 \mathrm{E}+04$ & $4.85 \mathrm{E}+03$ & $8.23 \mathrm{E}+02$ \\
\hline $\mathrm{CV}$ & $9.97 \mathrm{E}-02$ & $9.89 \mathrm{E}-02$ & $9.96 \mathrm{E}-02$ & $9.93 \mathrm{E}-02$ \\
\hline $\mathrm{P}(\mu-3 \sigma)$ & $1.35 \mathrm{E}-03$ & $1.35 \mathrm{E}-03$ & $1.35 \mathrm{E}-03$ & $1.35 \mathrm{E}-03$ \\
\hline $\mathrm{f}_{\mathrm{s}}$ & 1.43 & 1.41 & 1.42 & 1.42 \\
\hline
\end{tabular}

In the same table, the mean and coefficient of variation are also reported. The coefficient of variation is close to $\mathrm{CV}=0.1$, a value prescribed to all stochastic parameters of the fatigue initiation law. By stopping the cyclic loading with a number of cycles less than mean minus three standard deviations, the safety factor is 1.42 with a probability of failure of $1.35 \times 10^{-3}$. This value is similar for the two stress range levels. The maximum reduction on stress range $\mathrm{R}$ due to hydrogen embrittlement is equal to $10.4 \%$.

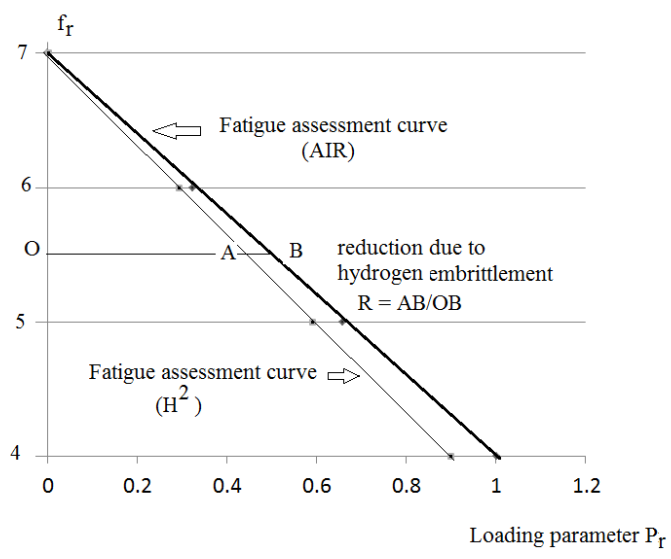

Fig. 6: Hydrogen embrittlement on fatigue resistance of X52 pipe steel presented in a fAD.

\section{SAFE DESIGN USING A SAFETY FACTOR FOR THE NUMBER OF CYCLES TO FAILURE}

Safe design against fatigue is made using a safety factor on the stress range or on the number of cycles to failure. In some codes, a safety factor of 10 is applied to the number of cycles to failure, and a safety factor of 2 on the stress range. The method that provides the most conservative design fatigue failure curve is chosen. Introducing a sefety factor of 10 on the number of cycles to failure leads to a new fatigue design curve, which is given by:

$\Delta \sigma=\sigma_{i, N / 10}^{\prime} \cdot\left(\frac{N_{r}}{10}\right)^{-\beta}=\sigma_{i,}^{\prime}\left(N_{r}\right)^{-\beta}$

with the new fatigue coefficient $\sigma_{f, N / 10}^{\prime}$

$$
\sigma_{i, N / 10}^{\prime}=\sigma_{f}^{\prime} /\left(\frac{1}{10}\right)^{-\beta}
$$


Table 8: Initial and design assessment points under air and with hydrogen embrittlement

\begin{tabular}{|l|l|ll|}
\hline Air & $\begin{array}{l}\text { Initial assessment } \\
\text { point }\end{array}$ & $\begin{array}{c}\text { Design } \\
\text { Asessment } \\
\text { mean) }\end{array}$ & point \\
\hline $\begin{array}{l}\text { Stress range } \\
(\mathrm{MPa})\end{array}$ & 286.6 & 286.6 & \\
\hline $\begin{array}{l}\text { Number of } \\
\text { Cycles }\end{array}$ & 500000 & 50000 & point \\
\hline $\begin{array}{l}\text { With hydrogen } \\
\text { embrittlement }\end{array}$ & $\begin{array}{l}\text { Initial assessment } \\
\text { point }\end{array}$ & $\begin{array}{l}\text { Design } \\
\text { Asessment } \\
\text { (mean) }\end{array}$ & 256.80 \\
\hline $\begin{array}{l}\text { Stress range } \\
(\mathrm{MPa})\end{array}$ & 256.80 & 50000 & \\
\hline $\begin{array}{l}\text { Number of } \\
\text { Cycles }\end{array}$ & 500000 & & \\
\hline
\end{tabular}

The following conditions are chosen as an example: the number of applied fatigue cycles is 500000, which corresponds to a stress range of 286.6 MPa. By introducing a safety factor of 10 on the number of cycles, the same stress range is maintained, but the expected number of cycles to failure is divided by 10 . Using the Monte Carlo method, the failure probability is determined for the probabilistic design conditions. Different design conditions are summarised in Table 8 . The distribution of the number of cycles is considered to be normal with a coefficient of variation of $\mathrm{CV}=0.1$.

Table 9: Number of fatigue cycles corresponding to each type, failure probability and associated safety factor.

\begin{tabular}{|r|r|r|r|}
\hline \multicolumn{1}{|l|}{$\mathrm{Nr}$} & Type & P & \multicolumn{1}{l|}{$\mathrm{F}_{\mathrm{s}}$} \\
\hline 500000 & $\mu$ & 0.5 & 1 \\
\hline 450000 & $\mu-\sigma$ & 0.16 & 1.11 \\
\hline 350000 & $\mu-3 \sigma$ & 0.0013 & 1.42 \\
\hline 50000 & $\mathrm{~N} / 10$ & $1.12 \mathrm{E}-19$ & 10 \\
\hline 300000 & $\mathrm{~N}^{*}$ & $1.00 \mathrm{E}-06$ & 1.66 \\
\hline
\end{tabular}

Failure probability and the associated safety factor for a number of cycles corresponding to a mean value $(\mu)$, the mean minus one standard deviation $(\mu-\sigma)$, and the mean minus three standard deviations $(\mu-3 \sigma)$, are reported in Table 9.

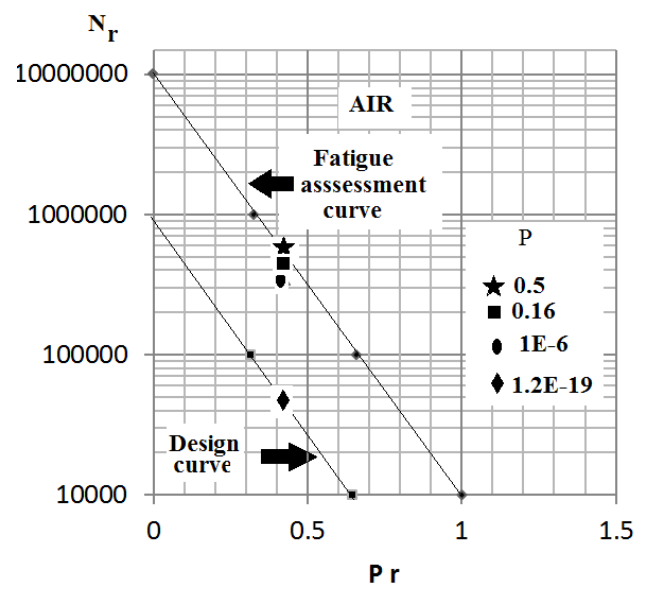

Fig. 7: Assessment points for various safety factors applied to the number of cycles to fatigue failure and corresponding probabilities. 
In this table, the probability of failure associated with the number of design cycles divided by 10 and the number of cycles $\mathrm{N}^{*}$ corresponding to usual design probability of failure $\left(10^{-6}\right)$ are reported. A very low probability of failure is obtained using a safety factor of 10 on the number of cycles to fatigue failure. This value and probably are not economically acceptable, and and according to the structural weight Therefore the safety factor of 2 on the stress range is preferable. An acceptable design probability of failure of $10^{-6}$ is obtained with a safety factor on the number of cycles of 1.66. The assessment points for various safety factors applied to the number of cycles to fatigue failure, and the corresponding probabilities, are reported in Fig. 7.

\section{CONCLUSIONS}

To guarantee a fatigue lifetime with a conventional and low probability of failure, the probabilistic fatigue assessment diagram is a performance tool. fAD is based on the fatigue failure assessment curve, which is material-dependent through the fatigue exponent, endurance limit and upper stress range corresponding to the low cycle fatigue domain. The two aforementioned limits corresponding to the fatigue limit and the low cycle domain require the use of a double-truncated stress range distribution. From this truncated distribution, it is possible to find the failure probability and its associated safety factor. fAD has been used to estimate the reduction of fatigue life duration due to hydrogen embrittlement.

The use of a safety factor of 10 on the number of cycles to failure is discussed; this leads to a very conservative approach. A safety factor of 1.66 gives an economical and acceptable probability of failure of $10^{-6}$.

\section{REFERENCES}

[1] SINTAP: Structural integrity assessment procedure. Final report. EU project BE95-1462, Brite Euram Programme, Brussels; 1999.

[2] Pluvinage G, Schmitt C. Probabilistic approach of safety factor from failure assessment diagram. In: Kadry

S, El Hami A, editors. Numerical methods for reliability and safety assessment. Multiscale and multiphysics systems; 2014, p. 549-577. ISBN: 978-3-319-07166-4.

[3] Jallouf S, Pluvinage G, Casavola K. and Pappalettere C. "A Probabilistic fatigue assessment diagram to get a guaranteed lifetime with a low probability of failure"

Procedia Structural Integrity : 2447-2455, (2016).

[4] Capelle J, Gilgert J, Pluvinage G . "Hydrogen effect on fatigue life of a pipe steel".

Safety, Reliability and Risks associated with water, oil and Gas pipelines Editeur G Pluvinage et M Elwany, Springer.pp 205-2218,(2007).

[5] Pluvinage G, Sapounov V. Prévision statistique du comportement des matériaux». Editeur CEPADUES, (2006).

[6] Anderson TW, Darling DA. A test of goodness-of-fit. J Am Stat Assoc 1954;49:765-9. 